\title{
RAZVOJ MODELA MUZEJA SIGURNOSNE OPREME ${ }^{4}$
}

\section{SAŽETAK}

Sigurnost na radu bilježi svoje početke od ranih civilizacija, pa sve do današnjeg modernog doba. Kako se povijest sigurnosti na radu ne bi zaboravila, potrebno je stvoriti muzej u kojem će se omoguciti njen prikaz, o čemu govori ovaj rad. U radu su dani povijesni teorijski prikazi zaštite na radu u pojedinim područjima ljudske djelatnosti. Daje se opširan pregled muzeja, što uključuje razne planove, artefakte, modernu sigurnosnu opremu, aktivnosti, ostalu opremu za rad, elektronički muzej i troškove. Zadatak muzeja sigurnosne opreme je educirati ljude o važnosti sigurnosti na radu, što znači implementirati svijest o zaštiti na radu, kako bi se postigla planirana prevencija s ciljem sprječavanja ili smanjena rizika na radnom mjestu i izvan njega. Prikazat ćemo rezultate projekta i predviđanja za daljnji razvoj.

Ključne riječi: sigurnost na radu, zaštita na radu, edukacija, muzej

\section{UVOD}

Sigurnost na radu danas predstavlja određenu disciplinu koja se nalazi u svim porama ljudskih djelatnosti. Sigurnost se povezuje s pojmovima kao što su zaštita, osiguranje, zdravstvo, radni uvjeti, ljudska prava, ljudski međuodnosi itd. Međutim, sigurnost na radu kao pojam te njezin razvoj rijetko se spominju u starijoj literaturi.

Kako bi se prikazao njezin razvoj i predstavio široj javnosti, moguće je osnovati muzej sigurnosne opreme koji bi mogao sadržavati artefakte iz prošlosti. Također, muzej može sadržavati i modernu sigurnosnu opremu za usporedbu s artefaktima, pa i imati poseban odjel za djecu i mladež u kojem će se ona putem raznih igara obrazovati o sigurnosti. Po završetku, muzej može biti dostupan u elektroničkom obliku putem interneta.

Muzej je zamišljen da tematski prikazuje područja poput agrikulture i rudarstva, ali i područje osobne zaštite opreme, koje će biti opisano u ovom radu. Cilj rada je teorijski prikazati nastajanje muzeja sigurnosne opreme, njegove elemente, njegovu važnost i zadaću, svrhu, razvoj i troškove.

1 Struc. spec. ing. sec., Calle castell num 5, 25139 Menarguens, Španjolska. E-mail: mario.milicic.1993@gmail.com

2 Dipl. ing. sig., predavač, Veleučilište u Rijeci, Vukovarska 58, 51000 Rijeka, Hrvatska. E-mail: kdundovic@veleri.hr

3 Dr. sc., profesor, Veleučilište u Beji, Rua Pedro Soares, Campus do Instituto de Beja, Beja, Portugal. E-mail: rui.isidoro@ipbeja.pt

4 Datum primitka rada: 12. 1. 2018.; datum prihvaćanja rada: 1. 3. 2018. 


\section{POVIJEST ZAŠTITE NA RADU}

Zaštitana radujemultidisciplinarnaznanostkoju stručnjacigodinamaizgrađujuinterdisciplinarnim pristupom i kao takva je tek u početku svog razvoja. Ljudi su tisućama godina određene, danas lako izlječive profesionalne bolesti, poput onih izazvanih prašinom u rudnicima, pripisivali kletvama i duhovima. Nije bilo interesa ni uvjeta da se stvori znanstvena disciplina (https://repozitorij.vuka.hr, 5. 1. 2018.).

Krajem 19. stoljeća po prvi put u povijesti u tvornicama se pojavljuju liječnici koji primjenjuju svoje medicinsko znanje na proces proizvodnje, proučavaju tvari koje radnici koriste, bolesti koje zbog njih nastaju te počinju razmišljati kako da spriječe uočene bolesti. Krajem 19. stoljeća kreće razvoj medicine rada koja znatno utječe na bolju kvalitetu života i zaštitu na radu (https://repozitorij. vuka.hr, 5. 1. 2018.).

Slika 1. Ručak na vrhu nebodera

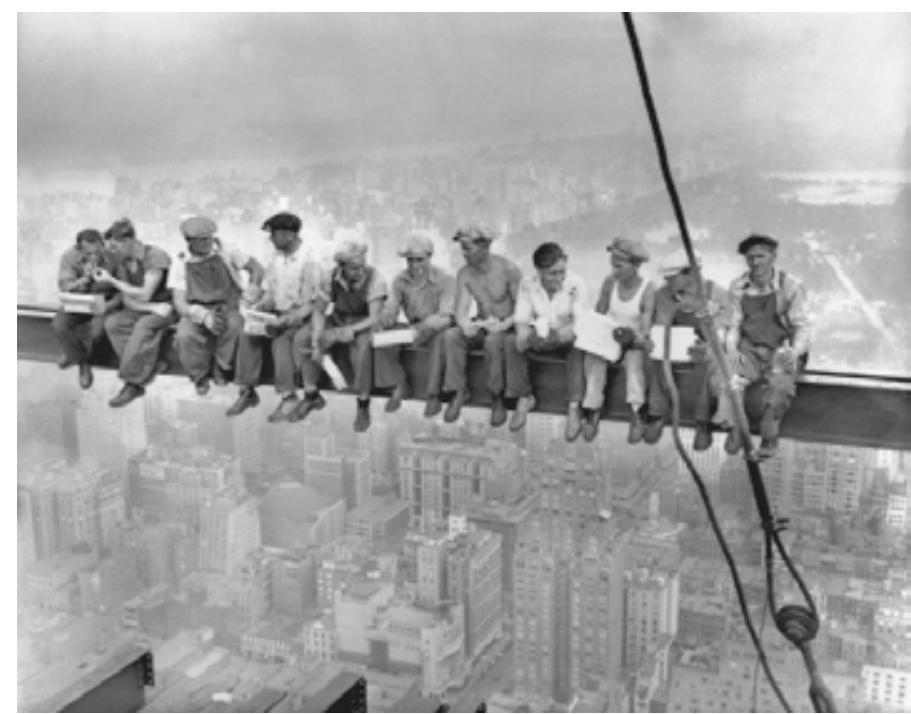

Izvor: https://www.europosters.eu/posters/lunch-on-a-skyscraper-v57

Danas je zaštita na radu temelj svakog ozbiljnog poduzeća i prisutna je u većini zemalja. Moderna zaštita na radu stavlja se ispred samog procesa rada, što znači da primarna zadaća poduzeća nije profit, već zdravlje i sigurnost radnika. Ona zahtijeva skup stručnjaka kojima je dužnost provoditi, kontrolirati i unaprjeđivati radne uvjete, kako bi se dostigao zadovoljavajući stupanj zaštite na radu (https://repozitorij.vuka.hr, 5. 1. 2018.).

\section{1 Povijest zaštite na radu u poljoprivredi}

Tijekom rada na polju u vrućim ljetnim mjesecima najvažnija mjera zaštite na radu bila je stalna opskrba svježom vodom, lagana odjeća te šešir koji je služio za zaštitu od sunca. Ipak, postojala su određena osobna zaštitna sredstva koja su se koristila. 
Tijekom košnje trave radnici su imali kožne zaštite za ruke u obliku polurukavica. Korištenjem zaštite radnici bi smanjili mogućnost dobivanja žuljeva. Na kraju radnog dana zaštitna oprema morala se oprati vodom kako ne bi nastale određene infekcije.

Pri radu s pčelama radnici su imali metalnu zaštitnu masku. Zaštitna maska je imala vrlo male otvore kako pčele ne bi mogle doprijeti do radnikovog lica, no s druge strane dovoljno velike otvore kako bi radnik imao preglednost. Također, zaštitna maska je imala dodatni produžetak u obliku plašta koji je služio za zaštitu vrata od uboda pčela ili drugih insekata.

Pri košnji trave u prošlosti se koristio srp. Srp je svojim karakterističnim oblikom i oštricom kojom siječe predstavljao opasnost za radnikove ruke, stoga su radnici od drveta napravili zaštitna sredstva za prste, kako se ne bi ozlijedili u radu.

Škare su također bile poljoprivredni alat koji je služio u razne svrhe, od sječe raznih lako lomljivih materijala pa sve do šišanja ovaca. Škare su u prošlosti bile rađene od metala, što znači da su bile teške te su mogle uzrokovati žuljeve na radnikovim rukama. Zbog toga su na škare bili stavljani drveni oblozi od pluta koji su sprječavali nastajanje žuljeva.

Slika prikazuje primjer drvene zaštite za prste iz muzeja Museu Etnográfico Serpa iz Portugala.

Slika 2. Drvena zaštitna oprema za zaštitu prilikom košnje

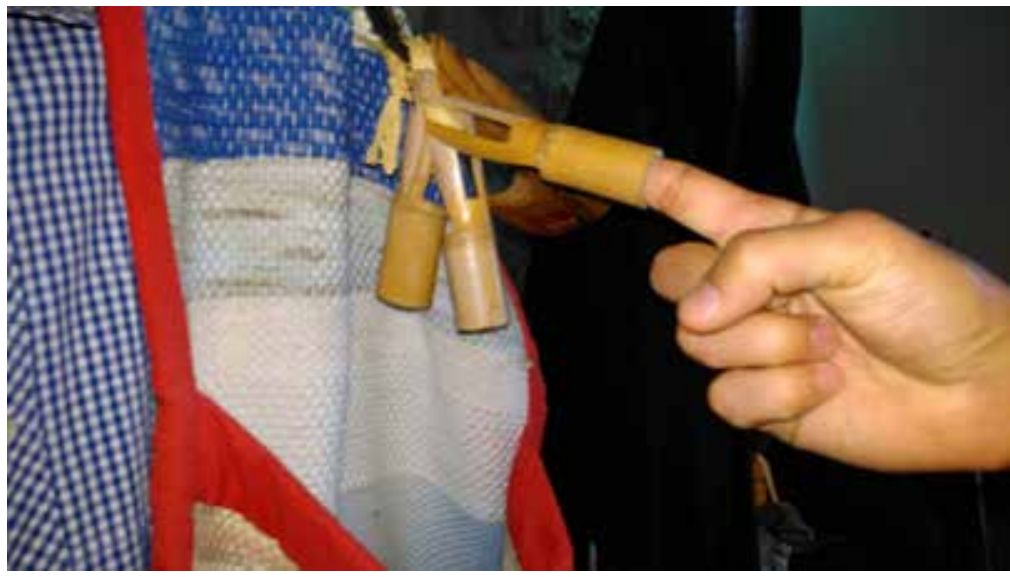

Izvor: izrada autora

Koliko god se poljoprivreda činila neopasnim, ali teškim fizičkim poslom, ljudi su brinuli o svojem zdravlju, o čemu svjedoči zaštitna oprema odnosno ergonomski oblikovano oruđe.

\subsection{Zaštita na radu u rudarstvu}

U prošlosti je rad pod zemljom predstavljao vrlo velik problem za radnike. Radnici su do kraja 20. stoljeća imali probleme s rušenjem zidova i stropova, ventilacijom, plinovima, požarima, eksplozijama, osobnom zaštitnom opremom itd. Probleme su vrlo teško rješavali, ali ne stoga 
što nisu imali ideje kako prevenirati probleme, već zbog toga što tehnologija nije bila razvijena, a problem je predstavljala i osobna zaštitna oprema.

Uzevši u obzir da su zaštitne kacige bile primarna zaštita rudara, kroz povijest možemo uočiti kako su izrađene od različitih materijala, veličina i oblika. Ergonomski nisu bile razvijene do sredine 20. stoljeća, te nisu imale dodatne nastavke, poput stalka za lampu.

U početku rudarske kacige, zapravo, nisu ni bile kacige, već kape ili pokrivači za glavu, koji su služili za zaštitu od prašine. Zaštitna „kaciga“ bila je vrlo jednostavna i zadovoljavala je minimalne uvjete. Kacige su bile izrađene od metalnih prstena univerzalnih veličina u obliku plašta te su se samo postavljale na radnikovu glavu. Kasnije su zaštitne kacige i dalje bile uglavnom univerzalnih veličina, no s određenim poboljšanim parametrima. Bile su izrađene od punog metala, što znači da su imale vrlo dobru zaštitu protiv udaraca, ali i veliku masu, pa su bile teške za radnikovu glavu. Kacige su imale ugrađene nosače za lampu, što im je omogućilo bolju preglednost u rudniku. Od kraja 20. stoljeća pa sve do danas kacige su doživjele vrlo bitne preinake. Željezo kao materijal izrade zamijenila je plastika. Plastika je zadržavala veliku otpornost na udarce, a zbog činjenice da je bila laganija, bila je puno lakša i ugodnija za nošenje. Unutar školjke kacige dodavala se kolijevka koja je omogućavala zatezanje i onemogućila ispadanje kacige s radnikove glave. Nosač za lampe ostao je nepromjenjiv, a počeli su se ugrađivati nosači za antifone. Povijesni razvoj zaštitnih kaciga prikazan je na slici 3 iz muzeja Museu Municipal de Aljustrel iz Portugala.

Slika 3. Prikaz rudarskih kaciga kroz povijest

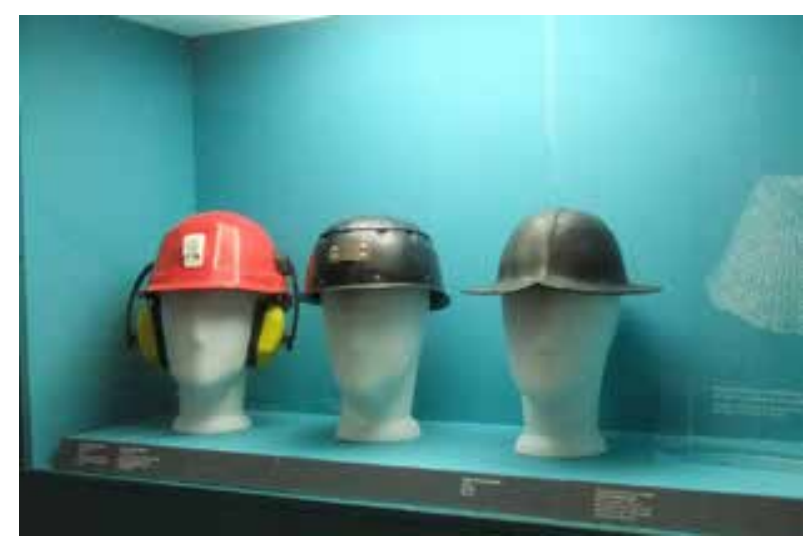

Izvor: izrada autora

Kasnije, osim zaštitne kacige koja je u početcima bila jedini dio osobne zaštitne opreme, počela su se koristiti i zaštitna odijela koja su bila otporna na habanje. Također su se počele koristiti zaštitne cipele izrađene od grube i tvrde životinjske kože. Razvojem tehnologije počele su se razvijati zaštitne maske, zaštitne rukavice, vodonepropusna odijela itd. 


\subsection{Povijest osobnih zaštitnih sredstava}

Povijest osobne zaštitne opreme počinje još od antičkih vremena, kada su vojnici nosili zaštitna pokrivala za glavu, lice i tijelo kako bi se zaštitili od neprijatelja. Velik dio opreme bio je vrlo težak te bi, primjerice, vojnik koji je pao s konja, izgubio od težine snagu i nije imao snage ponovno ga uzjahati bez pomoći (https://www.universalclass.com, 5. 1. 2018.).

$U$ industriji su kovači nosili zaštitnu ručnu opremu, pregače ili štitnike protiv opeklina koje bi zadobili prilikom manipulacije užarenim metalima. U mnogo je slučajeva uporaba osobne zaštitne opreme bila neobvezna i nije bilo obvezujućih propisa za zaštitu radnika. Smatra se da je u 16. stoljeću pronađen prvi respirator Leonarda da Vincija koji je trebao zaštititi nosača otrovnog praha kojim su se punila oružja (https://www.howequipmentworks.com, 5. 1. 2018.).

Početkom 1800-ih brodograditelji su stavljali kape u katran i ostavljali ih pod suncem kako bi se skrutile. Kada bi otvrdnule, kape bi bile dovoljno jake da bi mogle zaštititi glave od udarca objekta s visine (https://en.wikipedia.org, 5. 1. 2018.).

Osobna zaštitna oprema pronalazi se u raznim oblicima, izrađena od različitih materijala. Služila je kao zaštita ljudi u svim aspektima njihova života. Ona se smatra vrlo bitnim segmentom sigurnosti na radu i predstavlja glavni element muzeja sigurnosne opreme.

\section{MUZEJ SIGURNOSNE OPREME}

Kako bi povijest zaštite na radu u rudarstvu, poljoprivredi, povijest osobne zaštitne opreme te sva ostala povijest zaštite na radu bila teorijski prikazana, moguće je stvoriti muzej sigurnosne opreme koji ćemo detaljnije opisati.

Muzej sigurnosne opreme zamišljeno je fizičko mjesto u kojem glavnu zbirku artefakata (muzejske građe) predstavljaju osobna zaštitna sredstva koja su se upotrebljavala prilikom obavljanja određenih poslova na radnim mjestima u određenim ljudskim djelatnostima.

Zbirka odabrane muzejske građe iz određenih ljudskih djelatnosti, kao i sam muzej, moraju nositi određenu poruku posjetiteljima muzeja, a to su:

1. Razumijevanje važnosti zaštite na radu i zaštite od požara na radnim mjestima

2. Implementacija svijesti o sigurnosti na radu

\section{Obrazovanje o artefaktima i njihovo proučavanje.}

Općenito gledajući, muzej sigurnosne opreme predstavlja edukacijsko mjesto u kojem se izučava važnost zaštite na radu kao humanog zanimanja. Zaštita na radu je relativno nova disciplina koja je još u razvoju. Osnivanjem muzeja sigurnosne opreme postiglo bi se unaprjeđenje važnosti ove discipline. 


\section{1 Misija, vizija, cilj i strategija muzeja}

Misija muzeja sigurnosne opreme je osigurati svim posjetiteljima kvalitetnu uslugu, odnosno, obrazovanje, podučavanje i informiranje o pojmovima vezanima za zaštitu na radu i zaštitu od požara. Navede usluge obuhvaćaju stjecanje znanja iz područja osobnih zaštitnih sredstva i zaštite na radu na radnim mjestima, kao i izvan njega.

Glavna vizija muzeja sigurnosne opreme je biti vodeći muzej u Republici Hrvatskoj, koji bi sadržavao sve potrebne elemente za potpuno obrazovanje djece i odraslih u pogledu zaštite na radu i zaštite od požara. Također, vizija muzeja je prikazivanje sadržaja putem internetske stranice, otvaranjem edukacijskog centra za djecu i mladež te putem određenih aktivnosti kao što su posjećivanje određenih ustanova.

Strategija muzeja sigurnosne opreme podijeljena je na godišnje i sezonske aktivnosti. Godišnje aktivnosti predstavljaju kontinuirani (dugoročni) rad muzeja, što uključuje stalan sadržaj muzejske građe i edukativne opreme. Sezonske aktivnosti uključuju kratkoročne aktivnosti koje se povezuju s određenim ljudskim djelatnostima. To su, primjerice, određene igre za djecu i mladež, kratkotrajne izložbe vanjskih suradnika, posjećivanje određenih ustanova i sl.

Cilj muzeja sigurnosne opreme je implementirati znanje i važnost zaštite na radu i zaštite od požara u sve posjetitelje muzeja. Također, cilj muzeja je promicanje kulture zaštite na radu kao humane discipline, koja je potrebna u svakome poduzeću.

\subsection{Osnivanje muzeja sigurnosne opreme}

Prilikom osnivanja muzeja sigurnosne opreme prethodno se moraju zadovoljiti sljedeći uvjeti:

1. Muzejska građa

2. Muzejska dokumentacija

3. Prostor

4. Oprema i sredstva za rad

5. Stručno osoblje.

Muzejska građa su civilizacijska, prirodna i kulturna materijalna i nematerijalna dobra koja su dio nacionalne i opće ljudske baštine. Drugim riječima, muzejska građa podrazumijeva sve vrste predmeta koji se sakupljaju, opisuju i prezentiraju kao muzejski predmeti. Uz muzejsku građu prilaže se i muzejska dokumentacija (Zakon o muzejima, NN 110/15).

Muzejski prostori dijele se prema namjeni i prema režimu pristupa. Prema namjeni, muzejski se prostori dijele na:

1. Čuvaonicu: zatvorenu, otvorenu, studijsku i trezor

2. Izložbeni prostor: za stalne i povremene izložbe

3. Prostor za muzejsku dokumentaciju: čuvaonicu muzejske dokumentacije

4. Prostor za edukativni rad: radionicu, igraonicu, predavaonicu 
5. Restauratorsku i preparatorsku radionicu: prema vrsti predmeta

6. Prostor za prijam građe i manipulaciju njome

7. Knjižnicu i spremište knjižnične građe

8. Prostor za rad s korisnicima: čitaonicu s pristupom informacijsko-dokumentacijskom sustavu, prostor za uvid u muzejsku građu i muzejsku dokumentaciju

9. Prostor za prijam novih predmeta (karantena)

10. Radionicu za tehničku pripremu izložbi

11. Fotografski studio

12. Prijamne prostore: ulazni, informativni punkt, garderobu, sanitarni čvor

13. Radne sobe: za stručno i tehničko osoblje, upravu muzeja i administraciju

14. Prodajne i ugostiteljske prostore: knjižaru, suvenirnicu, kavanu, restoran

15. Ostale prostorije (Zakon o muzejima, NN 110/15).

Kriteriji za određivanje namjene prostora u muzejima jesu muzeološka koncepcija, opseg i vrsta muzejske građe i muzejske dokumentacije, broj i struktura muzejskog osoblja, mjesto u Sustavu muzeja Republike Hrvatske, ustrojeni odjeli knjižnice, arhiva, restauratorske i preparatorske radionice i dr. Odnos veličine prostora prema namjeni razrađuje se muzeološkom koncepcijom pojedinog muzeja, koju odobrava Hrvatsko muzejsko vijeće (Zakon o muzejima, NN 110/15).

Muzej mora imati odgovarajuću opremu koja osigurava uvjete za obavljanje muzejske djelatnosti, s obzirom na namjenu prostorija, režim dostupnosti i mjesto u Sustavu muzeja Republike Hrvatske. Oprema u prostorima u kojima se čuva i izlaže muzejska građa i muzejska dokumentacija mora biti u skladu s potrebama provođenja mjera preventivne zaštite (Zakon o muzejima, NN 110/15).

Stručno muzejsko osoblje čine zaposlenici u muzejima i galerijama te muzejima, galerijama i zbirkama unutar pravnih osoba koji ispunjavaju uvjete za postavljenje u odgovarajuća stručna muzejska zvanja, odnosno zvanja za obavljanje stručnih poslova u muzeju i galeriji te muzeju, galeriji i zbirci unutar pravne osobe, kao i pomoćnih stručnih poslova (Zakon o muzejima, NN 110/15).

Prilikom osnivanja muzeja potrebno je uzeti u obzir i ostale pravne akte, zakone i pravilnike, koji su u vezi s muzejom i njegovim radnjama. Također je bitna suradnja s ljudima iz raznih područja kao što su arhitektura, inženjering, povijest itd.

\subsection{Opis idealne prostorije}

Idealna prostorija muzeja sigurnosne opreme trebala bi se sastojati od kombiniranog prostora, odnosno otvorenog i zatvorenog prostora.

Zatvoreni prostor trebao bi sadržavati svu muzejsku građu, kao i ostale elemente obrazovanja koji bi trebali bili postavljeni u muzeju. Također, zatvoreni prostor ne bi trebao sadržavati pregrade (dodatne zidove) kako bi posjetitelji imali bolji pregled na prostoriju. Naravno, prostorija mora biti dobro osvijetljena i pristupačna svim posjetiteljima. 
Otvoreni prostor trebao bi biti predviđen za obrazovanje djece, odnosno njihovu igru. Otvoreni prostor također bi se koristio za izložbe, prezentacije i slično, ali samo u slučaju idealnog vremena.

Shema 1. Idealni tlocrtni prikaz muzejskog prostora

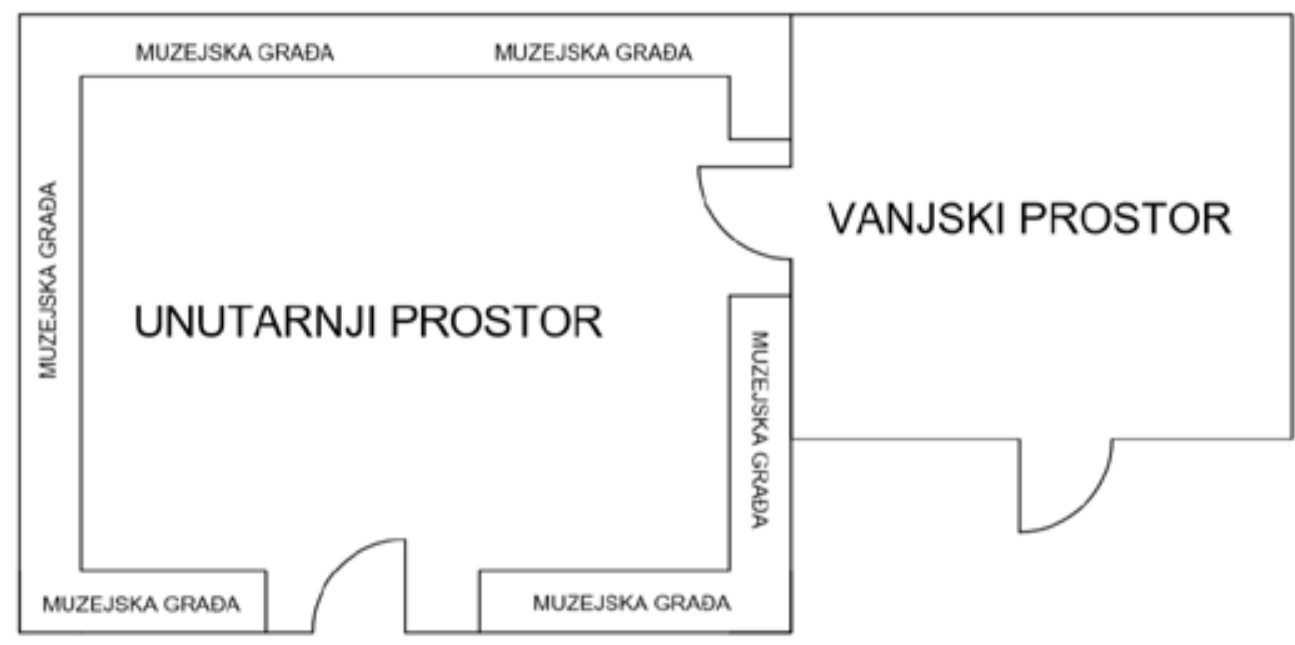

Izvor: izrada autora

Izgled idealne prostorije donosimo prema mišljenju autora. Prilikom izgradnje, kupnje ili iznajmljivanja prostorije potrebno je u obzir uzeti mišljenje stručnjaka.

\section{4 Tematske cjeline}

Tematske cjeline u muzeju sigurnosne opreme mogu biti neka od sljedećih područja ljudskih djelatnosti: poljoprivreda, rudarstvo, građevina, vatrogastvo, šumarstvo, industrija, brodogradnja itd.

Odabir tematskih cjelina najviše ovisi o raspoloživom broju artefakata (muzejke građe), a zatim o prostoru, novčanim sredstvima, transportu itd. Ako broj raspoloživih artefakata bude značajan, postoji mogućnost njihovog kronološkog pregleda. Količina tematskih cjelina u muzeju mora biti ograničena na samo nekoliko. Drugim riječima, muzej sigurnosne opreme ne bi trebao prikazivati više od tri stalne tematske cjeline. Stalne tematske cjeline moguće je i promijeniti tijekom određenog vremena. Također je preporučeno tijekom vremena u muzeju nadograđivati tematske cjeline ( $\mathrm{t} j$. muzejsku građu), kako muzej ne bi postao jednoličan i nezanimljiv posjetiteljima.

Isto tako sva muzejska građa mora imati opis na hrvatskome jeziku i po mogućnosti na određenom stranom jeziku (engleskom, njemačkom ili na nekom drugom jeziku).

\subsection{Muzej sigurnosne opreme kao obrazovni centar}

U današnjem svijetu, odnosno kompleksnom sustavu u kojem živimo, obrazovanje je značajan segment uspjeha pojedinca. $U$ prošlosti se obrazovalo s ciljem rada na jednom radnom mjestu 
koje bi donosilo prihode. Ljudi su težili više prema fizičkom i repetitivnom radu s/na strojevima, te nisu iskazivali prevelik interes za rad u drugim područjima. Naravno, tijekom obrazovanja su se izučavala ostala područja, no većina ljudi i dalje nije težila za napredovanjem.

Danas, kada su matematika, fizika, inženjerstvo, povijest, biologija, kemija i znanost sve više prisutni u društvu, ljudi su ponekad i „prisiljeni“ poznavati određena područja za koja se i nisu obrazovali. Potrebno je opće znanje kako bi se radni zadaci mogli obavljati što kvalitetnije.

Općenito gledajući, danas je obrazovanje sveprisutno, neizbježno, te teži prema cjeloživotnom obrazovanju. Jedan od segmenata obrazovanja u društvu može biti i muzej sigurnosne opreme.

Obrazovan je onaj tko živi u stalnom nastojanju da shvati sebe, društvo i svijet i djeluje sukladno tom razumijevanju. Obrazovanjem i edukacijom djece i odraslih u pogledu prošlosti zaštitne opreme, ljudi postaju svjesniji važnosti zaštite na radu. Takva vrsta edukacije vrlo je bitna jer se uočavaju bitni propusti prilikom rada, te se potiče na razmišljanje na koji način te iste propuste sanirati ili umanjiti.

\section{SADRŽAJ MUZEJA SIGURNOSNE OPREME}

Kako bi muzej sigurnosne opreme ostvario svoju misiju, viziju i ciljeve, potrebno je zadovoljiti sljedeće glavne uvjete:

1. Prikupiti dovoljan broj artefakta iz područja osobne zaštitne opreme

2. Osigurati modernu zaštitnu opremu kako bi se usporedila s artefaktima

3. Osigurati ostalu opremu za edukaciju, što uključuje postere, prijenosna računala itd.

4. Osigurati igračke za djecu i mladež iz područja osobne zaštitne opreme

5. Izraditi dugoročne i kratkoročne planove aktivnosti muzeja

6. Izraditi internetsku stranicu muzeja

7. Izraditi popis troškova

8. Predvidjeti razvijanje muzeja.

U sljedećim dijelovima rada ukratko će biti opisani svaki od navedenih uvjeta, navedeni razlozi zašto su oni bitni te prikazana mogućnost ostvarivanja tih istih uvjeta.

\section{1 Artefakti iz područja osobne zaštitne opreme}

Artefakti se profesionalno nazivaju muzejska građa i predstavljaju temelj skoro svakog muzeja. U današnje vrijeme postoje muzeji koji se baziraju na improvizaciji artefakta (hologrami) ili njihovim prikazivanjem putem slika, plakata, improvizacija itd. 
Artefakti su rukotvorine, odnosno, $u$ arheologiji to su nazivi za predmete koje su stvorili ljudi. Artefakti mogu biti izrađeni od raznih materijala, poput drva, kamena, keramike i sl. Oni mogu predstavljati određene nakite, oruđe, oružje, umjetničke predmete itd. (http://sjedi5.com, 5. 1. 2018.).

Proučavanje tih predmeta važno je za arheologiju jer se proučavanjem artefakata pružaju informacije o kulturama iz prošlosti i o njihovim načinima života.

Artefakti iz područja sigurnosti na radu, u slučaju muzeja sigurnosne opreme, predstavljaju osobna zaštitna sredstva koja su se koristila u radu u prošlosti.

Slika 4. Prikaz vatrogasne kacige od 1930. do 1970. godine

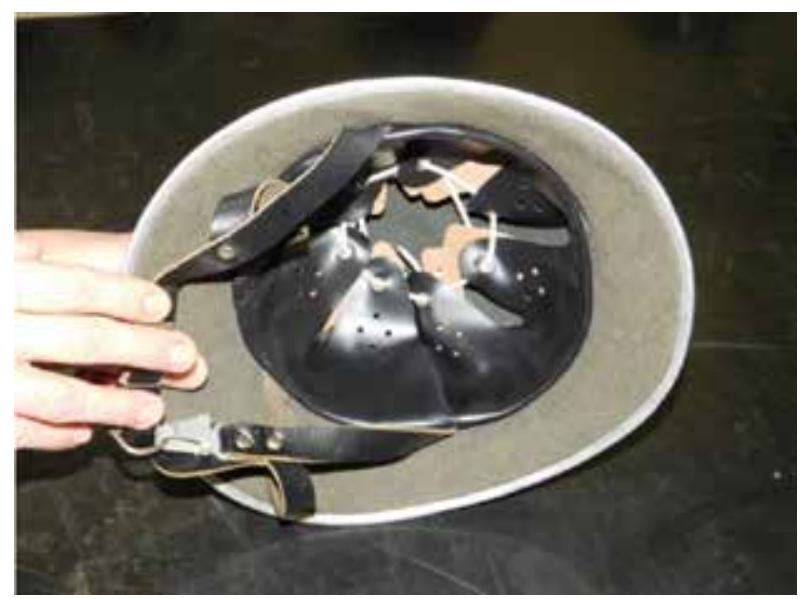

Izvor: http://zuznr.hr/

Sakupljanjem artefakta ostvario bi se prvi korak prema osnivanju muzeja sigurnosne opreme. Napominje se još jednom kako artefakti (muzejska građa) predstavljaju temelj gotovo svih muzeja na svijetu.

\section{2 Moderna osobna zaštitna oprema}

Današnji ljudski poslovi napreduju svakodnevno. Tehnologija se razvija, infrastruktura napreduje kvalitativno i kvantitativno, strojevi zahtijevaju sve veću edukaciju ljudi itd. Sva napredovanja popraćena su određenim rizicima, što znači da zaštita na radu mora pratiti moderne trendove.

Osim određenih inovacija, dokumenata, pravila, procedura itd., zaštita na radu također obuhvaća osobnu zaštitnu opremu. Današnja moderna osobna zaštitna oprema je tehnološki, ergonomski i učinkovito vrlo zadovoljavajuća i razvijena. Bez moderne opreme rad u određenim ljudskim djelatnostima ne bi bilo moguće obavljati (npr. rudarstvo).

Kako bi posjetitelji muzeja imali što bolji uvid u razliku o kvaliteti osobnih zaštitnih sredstva, kroz povijest pa sve do danas, oni spomenutu razliku moraju vidjeti, opipati, eventualno isprobati, proučiti te saznati određene spoznaje od stručnjaka u području zaštite na radu. Moderna zaštitna 
oprema važan je pokazatelj napredovanja tehnologije izrade nad osobnim zaštitnim sredstvima iz prošlosti. Ona također ukazuje na to koliko se unaprijedila kvaliteta zaštite za radnika.

Usporedba osobnih zaštitnih sredstava kroz povijest pa sve do danas ostavlja dojam na posjetitelje i pokazuje koliko se kultura zaštite na radu razvila. Također iz usporedbe sredstava posjetitelj može jasno vidjeti tehnološki pomak izrade.

Postavljanje moderne zaštitne opreme u muzej pridonosi modernizaciji muzeja u smislu muzejske građe. Ostavlja se jači dojam na posjetitelje, te pruža određenu širinu uvida u osobna zaštitna sredstva. Usporedbom sredstva posjetitelj može donesti određene zaključke tijekom posjeta (npr. o važnosti zaštite na radu).

\subsection{Moderna oprema za edukaciju}

U muzejima se posjetitelji primarno educiraju putem muzejske građe, tj. kroz moderne tehnologije. Navedene tehnologije u ovome radu planirane su za Muzej sigurnosne opreme.

Edukacija u muzeju putem modernih tehnologija obuhvaća:

1. projektore i prezentacije

2. holograme

3. plakate

4. prijenosna računala

5. ostalo.

Projektori su uređaji putem kojih se prikazuju razne prezentacije, filmovi, slike itd.; oni su glavni izvor sekundarnog obrazovanja za djecu i odrasle. Prikazivanje povijesti putem određenih projekcija ostavlja značajan dojam na posjetitelja. Slika govori više od tisuću riječi, što bi se moglo reći i za projiciranje povijesnih osobnih zaštitnih sredstva putem moderne tehnologije.

Hologrami predstavljaju vrlo visoku tehnologiju projekcija, ostavljaju jak vizualni dojam kod posjetitelja te prikazuju stvarnost u 3D obliku pomoću lasera. Postavljanjem holograma u muzej dobiva se suvremeni izgled muzeja.

Pomoću plakata mogu se slikovito i tekstualno prikazati određene poruke. Prednost plakata je u njihovim veličinama, koje mogu varirati do nekoliko metara. Plakati mogu biti raznih boja, oblika i prikaza.

Prijenosna računala u većini su slučajevima povezana s projektorima zbog prezentacija, jer pomoću njih se pokreće navedena radnja (projiciranje). Međutim, prijenosno računalo kao zasebna jedinica može omogućiti pojedincu samostalnu edukaciju. Pojedinac se može služiti prijenosnim računalom tako da pretražuje internet, pregledava videouratke, slike, prezentacije ili ostali sadržaj. 
Sva ostala oprema koja je moguća (npr. posteri), ali i općenito sva navedena oprema predstavljaju izvor obrazovanja za posjetitelje u određenoj mjeri. Svaka implementirana cjelina predstavlja dodatnu obrazovnu opremu.

\section{4 Obrazovanje djece i mladeži}

Obrazovanjem odraslih putem muzeja sigurnosne opreme postiže se podizanje kolektivne svijesti o važnosti sigurnosti na radu. No, nije bitna samo implementacija sigurnosti na radu kod odraslih, već je vrlo važno raditi s djecom i mladeži.

Obrazovanje djece i mladeži jedna je od ključnih zadaća odraslih osoba, kako bi se svijet u kojem živimo nastavio razvijati i unaprjeđivati. Obrazovanje djece mora se provoditi tijekom školskog obrazovanja, ali bi bilo poželjno takvo obrazovanje prošiti i izvan granica učionica. Iz tog razloga su se počele osnivati jezične škole, športski klubovi, umjetnički centri, ali i muzeji raznih tematika.

Općenito govoreći, djeca sigurnost ponajprije upoznaju u svojemu domu, putem informacija od roditelja, dok kasnije, djeca sigurnost počinju upoznavati izvan doma, primjerice u prometu.

Nakon obrazovanja o sigurnosti u vlastitome domu i izvan njega djeca i mladež susreću se sa sigurnošću u svakodnevnom životu kroz razne primjere - kod kućanskih poslova, u školi, na izletima itd. Sigurnost predstavlja (in)direktni pojam kod djece i mladeži, te se ona, kao takav pojam, pojavljuje u svakodnevnom životu.

No, postavlja se pitanje u kojem se periodu mladi susreću sa sigurnošću na radu te jesu li dovoljno educirani i kako se educiraju. Poznato je kako djeca najbolje uče kroz igru i s obzirom na tu činjenicu može se ispitati postoje li dovoljno razvijene igre sigurnosti.

Susretanje djece i mladeži s pojmom zaštite na radu obično započinje u srednjoškolskoj dobi (u razdoblju od 13. do 19. godine života). U pravom smislu riječi djeca se tada u teoriji (ponegdje i u praksi) susreću s pojmovima kao što su vatrogasni aparati, zaštitne maske, zaštitne kacige, rizik na radnom mjestu itd. Navedeni i slični pojmovi možda su i ranije spominjani tijekom života, no pretpostavlja se da su pojmovi povezani sa zaštitom na radu detaljnije opisani i približeni od strane stručne osobe u obrazovnim ustanovama u navedenom životnom razdoblju.

Detaljnije opisani pojmovi koji su povezani sa zaštitom na radu, kao i svi ostali pojmovi, putem raznih alata memoriraju se kod djece i mladeži. Snaga takvog memoriranja ovisi o što boljoj interpretaciji, koja se najbolje može manifestirati igrom i praktičnim upoznavanjem određene cjeline. Upravo iz tog razloga zasnovana je ideja osnivanja centra za djecu i mladež gdje bi se djeca i mladež kroz igru upoznavali s pojmovima zaštite na radu.

Centar zaštite na radu za djecu i mladež mogao bi se sastojati od područja određenih tematskih cjelina. Područja mogu prikazivati različita zanimanja u kojoj bi tematike igre bila zaštita na radu i zaštita od požara. Svaka tematika u određenom području granala bi se nadalje na zasebne cjeline. Primjerice, u području inženjerstva može se govoriti o strojevima, uređajima, alatima itd., dok se u području laboratorija može govoriti o laboratoriju hrane, vode, opasnih kemikalija i sl. Neka od područja su: 
1. tvornica čokolade

2. tvrtke za čišćenje

3. penjanje

4. inženjerstvo

5. recikliranje

6. medicina

7. novinarstvo

8. policija

9. energetika

10. laboratorij

11. televizija.

Svako nabrojeno područje treba imati određene igračke s kojima bi se djeca i mladež mogla služiti. Igračke moraju biti napravljene od plastike ili drugog materijala gdje je mogućnost od ozljeđivanja minimalna, bez oštrih rubova, velike mase itd. Neke od igrački i opreme s kojima bi se mladi mogli koristiti su:

1. plastične zaštitne oprema (kaciga, naočale itd.)

2. plastični i drveni alati (čekić, ručna pila, sjekira itd.)

3. tekstilna zaštitna oprema (reflektirajući prsluci)

4. igračke manjih dimenzija (traktori, kamioni itd.)

5. društvene igre.

Djeca i mladež koja bi se služila takvom opremom moraju biti raspoređena po grupama, koje bi odredili i vodili stručnjaci. Grupe moraju imati vremensko ograničenje igranja. Također, grupe moraju imati određen broj osoba koje moraju biti raspoređene po životnoj dobi. Isto je tako potrebno uzeti u obzir veličinu plastične i tekstilne zaštitne opreme, jer nije svaka osoba jednako fizički građena.

Posjetiteljima bi prilikom posjeta muzeju trebale biti omogućene različite aktivnosti koje bi unaprijed bile određene. Aktivnosti mogu varirati, odnosno, broj i tematika aktivnosti može se prilagođavati broju posjetitelja, godišnjem dobu, veličini prostora itd.

Važno je napomenuti kako je edukaciju djece i mladeži potrebno provoditi potpuno profesionalno, što znači da je potrebno osigurati profesionalnog radnika koji bi radio na takvom odjelu. 


\section{5 Aktivnosti u muzeju}

Aktivnosti u muzeju, ovisno o sadržaju muzeja, mogu biti podijeljene na dugoročne i kratkoročne aktivnosti.

Dugoročne aktivnosti su one aktivnosti koje se ponavljaju kontinuirano u vremenskom intervalu od 6 mjeseci ili više. Sadržaj takvih aktivnosti je stalan i ostaje nepromjenjiv. Postoji mogućnost korekcija unutar aktivnosti, što znači da se aktivnosti mogu promijeniti. Primjerice, ako bi aktivnost bila izložba artefakta iz područja rudarstva, a postoji i mogućnost kvalitetne izložbe sigurnosne opreme iz područja građevinarstva, tada se vrši zamjena aktivnosti o kojoj se unaprijed moraju napraviti planovi.

Kratkoročne aktivnosti su one aktivnosti koje su sadržajno i tematski promjenjive u određenom vremenskom intervalu. Svrha kratkoročnih aktivnosti je prikazati opširnost zaštite na radu, koja se ne može prikazivati tijekom dužeg vremena (primjerice gašenje požara u prošlosti s današnjom usporedbom ili kratkotrajne izložbe od vanjskih suradnika). Takve aktivnosti uklanjaju monotonost muzeja te povećavaju pažnju građana.

Svaka aktivnost u muzeju mora odgovoriti na sljedeće navode:

1. ideja i sadržaj prikazivanja

2. vremenski interval prikazivanja

3. ciljana grupa ljudi

4. cilj prikazivanja

5. isplativost prikazivanja.

Ideje kratkoročnih aktivnosti moraju imaju kvalitetnu i kreativnu tematiku. To je od iznimne važnosti zbog privlačenja pažnje posjetitelja. No, svaka ideja mora biti potkrijepljena sadržajem koji bi je predstavljao. Primjerice, gotovo je nemoguće prikazati svemirsku sigurnosnu opremu koja se koristila u prošlosti jer ona nije dostupna na području Republike Hrvatske. S druge strane, prikazivanje vatrogasnih vozila teoretski je moguće, s obzirom na to da je vatrogastvo razvijena grana Republike Hrvatske. Vremenski interval prikazivanja kratkoročnih aktivnosti mora biti unaprijed određen, te se određuje na temelju zadane teme i predviđenih broja posjeta. Ciljana grupa ljudi koja bi koristila kratkoročne aktivnosti mogu biti djeca, mladež, srednjoškolci, studenti, odrasli i umirovljenici. Aktivnost može biti određena za jednu ili više skupina. Određivanje ciljanje grupe ljudi ovisi o vrsti aktivnosti koja bi se prikazivala.

Cilj i poruka prikazivanja aktivnosti moraju biti jasno definirani. Svaki posjetitelj prilikom odlaska s aktivnosti trebao bi prepoznati ili naučiti poruku koja se prikazivala tijekom ili nakon aktivnosti.

\section{6 Elektronički prikaz muzeja}

Sve više ljudi danas može se i zna služiti internetom. Internet postaje jedan od glavnih sredstava izvora informacija. Putem interneta osoba može saznati određene informacije i podatke u vrlo 
kratkom vremenu. Upravo stoga muzej sigurnosne opreme mora biti dostupan na internetu u obliku internetske stanice. Prikaz muzeja sigurnosne opreme putem internetske stranice omogućio bi veću popularnost muzeja. Osobe bi tako putem internetske stranice saznale različite informacije o vremenskom radu muzeja, sadržaju i aktivnostima koje su dostupne, cijenama ulaznica itd. Također, na internetskoj stranici postoji i mogućnost prikazivanja slika muzejske građe, kao i ostalih edukacijskih materijala.

\subsection{Popis troškova}

Kao i svaka ustanova koja obavlja određenu djelatnost, tako bi i gradnja, osmišljavanje muzeja podrazumijevalo određene troškove. Troškovi mogu varirati (primjerice ovisno o godišnjem dobu), mogu se uvećavati (otvaranje novih prostorija), smanjivati (ljetno radno vrijeme) ili pak održavati na određenom nivou. S pretpostavkom da muzej obavlja određenu radnju, u nastavku su navedeni glavni troškovi muzeja:

1. materijalni troškovi (struja, voda, plin, dijelovi i sl.)

2. trošak rada (plaće, dodatci na plaću, prekovremeni rad i sl.)

3. ostali troškovi (čišćenje, održavanje i sl.)

4. administrativni troškovi (uredski materijal, najam prostora i sl.)

5. amortizacija.

Točan popis troškova najbolje se može utvrditi tijekom detaljnijeg planiranja. Dosad navedeni troškovi samo su glavni troškovi, te njihovi iznosi mogu varirati tijekom planiranja i rada muzeja. Troškovi su sastavni dio svakog posla, te je o njihovom vođenju potrebno angažirati stručnjaka.

\section{8 Razvijanje muzeja}

Ako bi muzej sigurnosne opreme bio u potpunosti kompletan obrazovni sustav, tada bi generalno sadržavao sljedeće cjeline:

1. muzejsku građu (artefakte)

2. modernu sigurnosnu opremu

3. odjel za djecu i mladež

4. internetsku stranicu.

Svaka obrazovna cjelina zasebno bi se razvija u budućnosti u većim ili manjim mjerama. No, kada se obuhvati razvijanje svake obrazovne cjeline, onda se govori o razvijanju muzeja u njegovim najbitnijim segmentima - znanju i kulturi. Nadalje će se pretpostavkama prikazati razvijanje muzejskih cjelina.

Razvijanje muzejske građe može se kretati u dva scenarija. Prvi scenarij predstavlja stagniranje muzejske građe, odnosno njezino planirano neproširivanje. Drugi riječima, sva prikupljena muzejska 
građa bila bi stalna, nepromijenjena cjelina u muzeju. Drugi scenarij predstavlja proširivanje muzejske građe, zbog sakupljenih novih artefakta koji bi se mogli izložiti. Smanjivanje muzejske građe nije planirano, s obzirom na to kako muzejska građa predstavlja temelj muzeja.

Moderna sigurnosna oprema ostavlja također dva moguća scenarija. Prvi scenarij je prikupljanje dovoljne količine moderne opreme koja bi u zadovoljavajućim mjerama prikazala usporedbu između prikupljene moderne opreme i artefakta. Takva prikupljena oprema može stagnirati ili se povećavati - ovisno o razvijanju muzejske građe. Drugi scenarij nevezan je za muzejsku građu i on zastupa praktično isprobavanje opreme. Svu opremu, ili dio prikupljene muzejske opreme, posjetitelji bi mogli isprobavati na sebi. Tada se moderna sigurna oprema mora prikupiti u dovoljnim količinama za predviđeni posjet ljudi.

Odjel za djecu i mladež može imati nekoliko mogućih scenarija. Prvi scenarij je prikupljanje određenih materijala za igru i obrazovanje, te ih tijekom vremena mijenjati, ali na kvalitativnoj razini. Drugi i treći scenarij predstavljaju kvantitativno povećanje ili smanjivanje materijala, dok kvalitativna razina može ostati ista ili pak promjenjiva. Posljednji scenarij prikazuje ideju „vanjskog obrazovanja", odnosno transport obrazovnih materijala u dječje domove, vrtiće, škole i ostala mjesta gdje se djeca i mladež sakupljaju.

Internetska stranica je fleksibilna i ona može ići u jednom smjeru, a to je njeno kvalitativno i kvantitativno izmjenjivanje. Na internetskoj stranici moguće je svakodnevno raditi promjene, izmjene i dopune koje ostavljaju određene informacija za posjetitelje.

Generalno gledajući, razvijanje muzeja može imati nekoliko mogućih scenarija. Svi su prethodno nabrojeni scenariji pozitivnog karaktera i ostavljaju dojam pozitivnog razvijanja u budućnosti. No, za razliku od svih prethodno pozitivno nabrojenih scenarija, Muzej sigurnosne opreme može također imati negativan scenarij - „propadanje“ i zatvaranje. Takav scenarij je također moguć, ako, primjerice, zainteresiranost javnosti bude ispod granice očekivanog, muzej se mora zatvoriti zbog pravnih razloga ili zbog određenog trećeg razloga. Prilikom otvaranja muzeja sigurnosne opreme potrebno je predvidjeti svaki mogući scenarij, kao i svaku moguću kombinaciju između obrazovnih cjelina.

\section{REZULTATI}

Projekt „Muzej sigurnosne opreme“ je jedinstven projekt po tome što je prihvatljiv u raznim zajednicama i moguće ga je ostvariti uz minimalne troškove. Muzej kao zasebna cjelina može sadržavati samo muzejsku građu, dok u svojoj potpunoj cjelini predstavlja svojevrsnu obrazovnu ustanovu.

Projekt trenutno bilježi svoje najveće rezultate u Portugalu. Prihvatio ga je Veleučilišni Institut Beja, gdje je i osmišljen i projektiran. Projekt posjeduje prostor za realizaciju, stručnu i novčanu pomoć. Projekt ima podršku portugalske državne institucije Autoridade para as Condições de Trabalho (ACT). Muzej sigurnosne opreme predstavljen je na nacionalnom kongresu II Encontro Nacional de Internacionalização do Ensino Superior Politécnico u gradu Beji. Muzej sigurnosne opreme ne predstavlja profitabilnu, već obrazovnu ustanovu. Drugim riječima, glavni cilj muzeja 
je obrazovanje mladih i odraslih o značajima sigurnosti na radu, a ne stvaranje prihoda. Glavni profit ustanove očituje se kroz uslugu koju pruža, a to je obrazovanje. Projekt je izvediv uz nekoliko uvjeta, a to su: troškovi, prostor, muzejska građa, stručna i pravna pomoć.

\section{ZAKLJUČAK}

Muzej sigurnosne opreme predstavlja originalnu ideju na području Republike Hrvatske koja još nije realizirana. Opis projekta koji je naveden u ovom radu može se izmijeniti, ovisno o području gdje bi se muzej nalazio, raspoloživim sredstvima za rad, idejama itd. Rezultati izrade projekta u Portugalu su pozitivni i očekuje se daljnje napredovanje. Tijekom 2017. godine projekt je započeo svoju izradu. 2018. godine organizirat će se prva izložba, dok pretpostavke govore da bi projekt trebao biti završen do 2022. godine.

Projekt muzej sigurnosne opreme predstavio se kao ostvarivi i prihvatljivi projekt u realnome vremenu. Također, projekt je moguće ostvariti u sklopu studentske prakse, kao što je slučaj u Portugalu na Veleučilišnom Institutu Beja. Praksa dosta često odstupa od teorije, pa tako i u ovome slučaju. Muzejska građa se mora kupiti ako je ne budu donirale fizičke ili pravne osobe, što predstavlja trošak. Potrebno je pronaći odgovarajući prostor i ljude koji bi bili zainteresirani za rad na projektu. Svaka navedena stavka u ovome radu nije ostvariva u kratkome roku. Potrebno se bazirati na ključne elemente muzeja (npr. muzejska građa), te potom na dodatne elemente (npr. holograme). Realizacija projekta zahtijeva puno strpljenja, rada i stručnosti. Projekt je potrebno poboljšati novim idejama i potrebno ga je predstaviti široj javnosti. Također, projekt je potrebno realizirati na području Republike Hrvatske.

\section{LITERATURA}

https://en.wikipedia.org (5.1.2018.)

http://sjedi5.com (5. 1. 2018.)

https://www.howequipmentworks.com (5. 1. 2018.)

Narodne novine, Zakon o muzejima, NN 110/15, 2015., https://www.zakon.hr (5. 1. 2018.)

Repozitorij Veleučilišta u Karlovcu, 2018., https://repozitorij.vuka.hr (5. 1. 2018.)

The History of Personal Protective Equipment, 2013., https://www.universalclass.com (5. 1. 2018.) 


\title{
DEVELOPMENT OF THE MUSEUM OF SAFETY EQUIPMENT ${ }^{4}$
}

\begin{abstract}
Safety at work has started to be developed in the first civilizations and it is still developed in the modern age. In order not to forget safety at work, it is necessary to create a museum that will present safety at work, and this paper will explore that. The paper presents historical and theoretical examples of safety at work in some specific areas of human activities. It gives a large-scale overview of the museum, which includes plans, artefacts, modern safety equipment, activities, other working equipment, electronic museum and costs. The aim of the museum is to educate people about the importance of safety at work, which means to increase consciousness about safety at work in order to achieve the planned prevention with the aim of eliminating or reducing risk in and outside the working place. The paper will show the results of the project and predictions offurther development.
\end{abstract}

Key words: safety at work, protection at work, education, museum

1 Professional Specialist Engineer of Safety and Protection, Calle castell num 5, 25139 Menarguens, Spain. E-mail: mario.milicic.1993@gmail.com

2 MEng, Lecturer, Polytechnic of Rijeka, Vukovarska 58, 51000 Rijeka,Croatia. E-mail: kdundovic@veleri.hr

3 PhD, Professor, Polytechnic of Beja, Rua Pedro Soares, Campus do Instituto de Beja, Beja, Portugal. E-mail: rui.isidoro@ipbeja.pt

4 Received: 12 January 2018; Accepted: 1 March 2018 